DOI: $10.25140 / 2411-5363-2021-2(24)-23-32$

\title{
Darina Hroncova
}

\section{COMPUTER MODELING IN MSC ADAMS/VIEW AS PART OF A MODERN APPROACH TO THE DESIGN OF MECHANICAL SYSTEMS OF ROBOTS}

The presented paper deals with the use of computer simulation in the design of a robot model with 4 degrees of freedom of movement. The MSC Adams program is used in the computer simulation, and the use of the Matlab program is also shown. The robot's mechanism is an open kinematic chain. During kinematic analysis, attention is paid to solving the direct problem of kinematics in MSC Adams and in Matlab. The result of the solution is the calculated trajectory of the movement of the selected point of the end effector. The trajectory is shown in graphical form. In Matlab, the magnitude of the position vector of the effector point is calculated as a function of time at the selected course of angular deflection in individual kinematic pairs at constant angular velocities in individual joints of the robot.

Keywords: manipulator; simulation; kinematic and dynamic analysis; matrix method.

Fig.: 10. Table: 2. References: 13.

Urgency of the research. The development of computer technology brings to the forefront the use of computer simulations of models of mechanical objects. This allows us to get a realistic view of the behavior of the created computer model, which represents a real object during the simulated motion. We can assess its functionality during the work process and make interventions in the model in order to improve its properties. The outputs of the quantities during the simulation obtained in graphical form allow us to assess the behavior of the model in real time during the work cycle.

Target setting. When working with computer modeling, we work with mathematical models.

A mathematical model is an abstract model that uses mathematical notation to describe the behavior of a system.

Mathematical models can be classified in several ways, some of which are:

- Linear and nonlinear. If the functions (conditions) and constraints are represented by linear equations, we denote the model as linear. If at least one of the conditions or constraints is represented by a nonlinear equation, the model is called nonlinear.

- Deterministic and stochastic. The deterministic model shows the same behavior after repeating the experiment under the same initial conditions, while in the stochastic model there is a coincidence, even if the initial conditions are the same.

- Static and dynamic. A static model does not consider an element of time, while a dynamic model does. Dynamic models are usually represented by recurrent or differential equations.

- Concentrated and decomposed parameters. If the model is homogeneous (in a consistent state in each part of the system), the parameters are concentrated. If the system is heterogeneous (different state in different parts of the system), the parameters are distributed. Distributed parameters are usually represented by partial differential equations [1-7].

Mathematical models can be further divided into two categories. The first is descriptive models that indicate the relationship between variables at a particular point in time, without explaining in themselves why this relationship occurs. The second category consists of dynamic models that describe how the values of variables change over time. These are differential equations. These models are also called analytical models. We try to solve the system of equations and find an equilibrium position. The equations show how the value of the variables changes. We can make this change in discrete time steps or continuously. In both cases, we can further investigate the behavior of the model defined by the equations in two ways. First, we can use an exact mathematical analysis of the problem to find a general solution of the equations or values of the variables for which the behavior of the model has stabilized. Second, we can use simulation, so we choose the initial values of the variables and determine the further behavior of the model by numerical calculation [1-7].

(C) Hroncova D., 2021 
Actual scientific researches and issues analysis. Computer analysis of robot models. Computer modeling can be divided according to the modeling process to mathematical modeling and "multibody" modeling. Mathematical modeling describes the whole model and its behavior using mathematical equations and algorithms. Mathematical equations defining the motion - equations of motion and equations describing kinematic dependencies between the individual chain members are used to define the properties of the elements of the solved model. However, derivation of these equations is time consuming and laborious and therefore this procedure is only suitable for simple models, for models with a low degree of freedom. Matlab, Maple, Mathematica are kinds of software used here.

Matlab is an environment that allows doing numerical computations, modeling and simulation.

Maple is a comprehensive computational software that allows analytical calculations, numerical calculations, graphical display of results and creation of a document describing the workflow.

Mathematica is focused on numerical and matrix tasks in various areas of engineering issues.

In multibody modeling we do not directly describe a mathematical model of the whole system. By using multibody modeling software, we can model the real elements of the system by using predefined bodies of respective geometry. There is a number of softwares that have different hardware and designer skill requirements. Some of them are Matlab/SimMechanics, Matlab/Simulink, Dynast, MSC Adams.

Matlab/SimMechanics - this Matlab extension was developed to address kinematics and rigid body dynamics.

Matlab/Simulink - this Matlab module was developed to create and solve dynamic systems using block diagrams.

Dynast allows simple mathematical calculations and simulations.

MSC Adams uses object-oriented programming environment with graphical output. Systems are defined directly by geometry of bodies, kinematic bonds, force effects and motion generators [8-10].

Analysis of existing research and publications. There is a variety of machines and devices consisting of spatial mechanisms and space-bound mechanical systems. We find them in material-handling machines as well as in precise mechanics products. They are also parts of various manipulators and robots. In order for the spatial mechanisms to be introduced more rapidly into practice and in order to increase their performance we need to replace the old computational practices that were largely intuitive and suitable for individual cases or small groups of mechanisms with more general, accurate and easily algorithmizable methods which are suitable for use with computing. The following chapters of the paper illustrate the matrix methods of compiling equations of motion. The matrix notation is an optimal approach due to its compactness, efficiency of applying various transformations and the suitability for using computers in numerical calculations. Structured mechanics were dealt with in works [1-3], more recently in [5-7]. Methods of mechanism description are described in works of Denavit and Hartenberg [4] and others. General methods of dynamic analysis of planar mechanisms are attributed to authors as Brát [5], Kozlov, Makaričev, Timofejev, Jurevič [6], Bejczy, Koplik, Leu, Haug, Stejskal [7], Valášek [7] and others. In our work, after the introductory theoretical part we show simple manipulator models compiled in MSC Adams-View.

Article objective. The presented paper shows the solution of kinematic analysis of mechanisms by classical methods of analytical mechanics matrix method and computer programs available today. Matrix method from analytical methods of solving mechanisms and computer programs Matlab and MSC Adams are used. In the kinematic analysis of the model of the robot, the following parts of the paper show the solution by the matrix method, then the model is created in the MSC Adams program and the matrix method is shown and its solution is performed using Matlab. 
TECHNICAL SCIENCES AND TECHNOLOGIES

The paper is devoted to the created robot model shown in the Fig. 1. From the point of kinematics, the mechanical structure of the robot represents an open kinematic chain. We consider 4 degrees of freedom of movement.

The manipulator consists of two arms and an end effector, the arms are mounted on a stand connected to a solid base. The stand provides the stability in operation. The arms are connected to each other by a rotating kinematic pair and by another rotating kinematic pair to the stand. The arms with the end effector rotate in a horizontal plane relative to the fixed stand. The working tool, which in our case is an end effector with two thumbs to hold the object of manipulation, is attached by a rotating kinematic pair to the second arm of the robot. The robot then performs the working motion with the end effector [1-7].
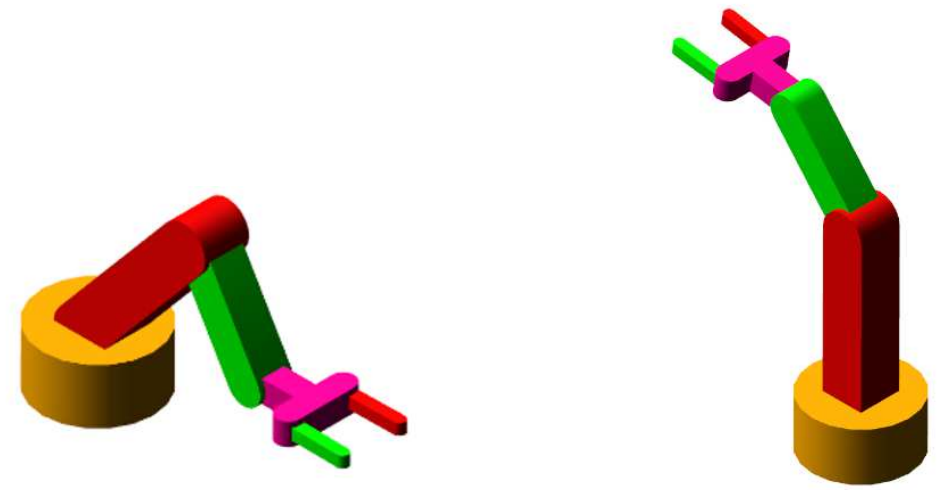

Fig. 1. Mechanical system of the robot

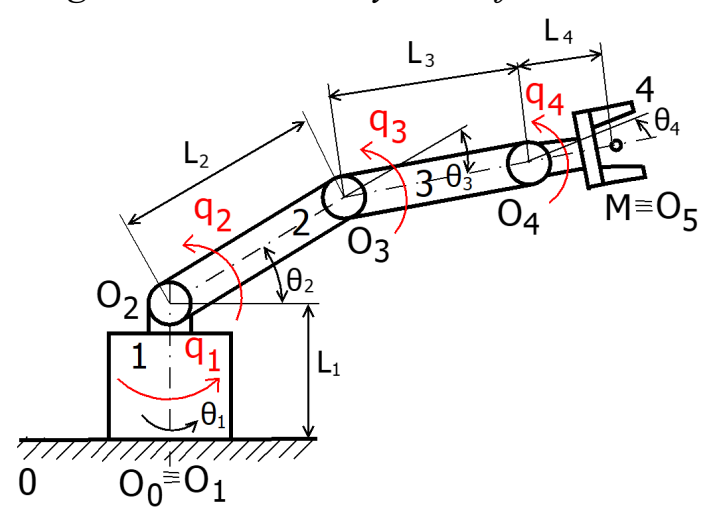

Fig. 2. Model of the robot with four degree of freedom

The aim is to describe the movement of the end-effector. We solve the forward kinematics of the robot [8]. The angle of rotation in kinematic pairs is denoted by angles $\Theta_{1}, \Theta_{2}, \Theta_{3}, \Theta_{4}$. The generalized coordinates determining the instantaneous position of the body are denoted by $\mathrm{q}_{1}, \mathrm{q}_{2}, \mathrm{q}_{3}, \mathrm{q}_{4}$ (Fig. 1), while for the generalized coordinates we apply $\mathrm{q}_{1}=\Theta_{1}, \mathrm{q}_{2}=\Theta_{2}, \mathrm{q}_{3}=\Theta_{3}$, $\mathrm{q}_{4}=\Theta_{4}$. The drives are mounted in rotating kinematic pairs (Fig. 2) [8].

When solving forward kinematics, we use the matrix method to determine the position of the effector endpoint. There are several methods for building a kinematic model of a robot. The most common method is the Denavit-Hartenberg kinematic modeling convention [4].

Fourth order matrices were introduced by J. Denavit and R.S. Hartenberg. Similarly, G.S. Kalicin solved some problems of planar and spherical mechanisms by matrix calculus. The possibility of using quaternions or biquaternions in the kinematics of the body was pointed out by J.Novák [5]. The general methods of analytical solution were dealt with by S.G. Kislicin and J.F. Moroshkin. In the kinematics of spatial mechanisms, the Czech mechanic V.Brát also introduced the use of matrix calculus [5]. 
For suitability and generality of the use of the matrix method speaks not only the possibility to contain the spaces of individual members directly in the equations, but also the convenience of use of a computer with sophisticated methods of numerical solution of systems of equations. Individual movements that take place at the same time can be described by matrix equations.

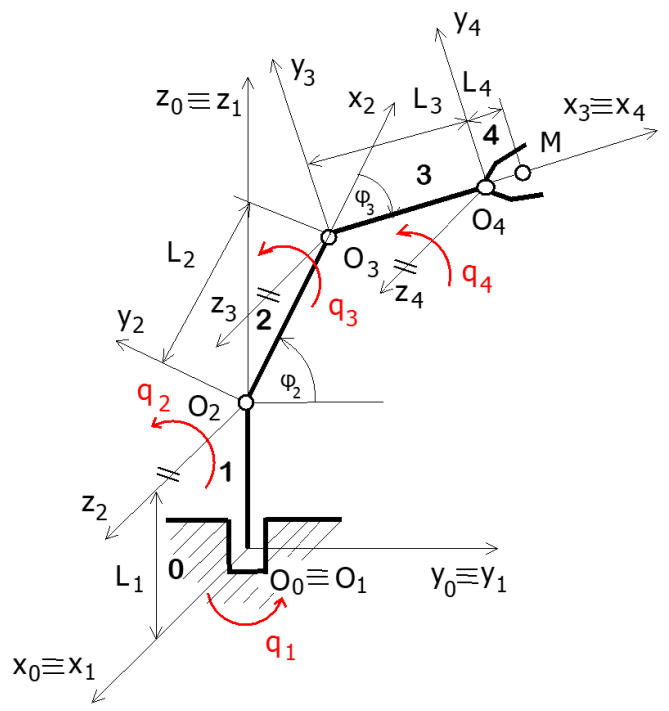

Fig. 3. Robot scheme: generalized coordinates $q_{1}, q_{2}, q_{3}, q_{4}$

We are interested in the position of the selected point of the end effector with respect to the global coordinate system in which the robot is located. A local coordinate system is associated with each member. The motion of a point located on a member with a local coordinate system is then described with respect to the global coordinate system (Fig. 3).

General overview of the system.

We assign a coordinate system $0_{i}, \mathrm{x}_{\mathrm{i}}, \mathrm{y}_{\mathrm{i}}, \mathrm{z}_{\mathrm{i}}$ to each member and we assign a generalized coordinate $\mathrm{q}_{\mathrm{i}}$ to each joint defined in the axis of rotation.

The axis $\mathrm{Z}_{\mathrm{i}}$ is oriented in the direction of the axis of the $(i+1)$-th joint. The axis $\mathrm{x}_{\mathrm{i}}$ is normal to the $\mathrm{z}_{i-1}$ and $\mathrm{z}_{\mathrm{i}}$ and is oriented from joint $i$ to joint $i+1$. The axis $\mathrm{y}_{\mathrm{i}}$ complements the rectangular, right-handed coordinate system.

Each member of the chain is characterized by two dimensions, a common normal distance $\mathrm{a}_{\mathrm{i}}$ along a common normal between the axes of the joints $i$ and $(i-1)$, and the second dimension is the angle of rotation $\alpha_{i}$ between these axes in a plane perpendicular to $a_{i}$ (Fig. 4).

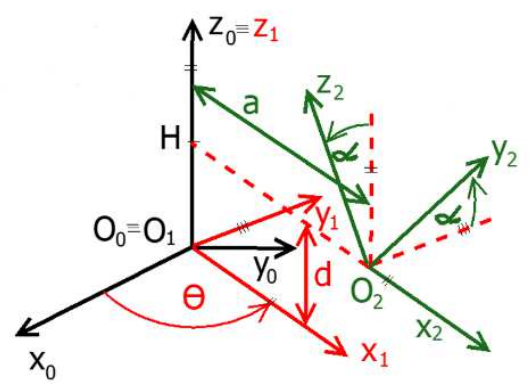

Fig. 4. Denavit - Hartenberg convention with parameters $\theta_{i}, d_{i}, \alpha_{i}, a_{i}$

Homogeneous transformation matrices contain information about the rotation between two coordinate systems and information about the distance between their origins. The purpose of introducing these matrices is to allow a more compact notation of position vectors expressed in different coordinate systems [1-7]. 
TECHNICAL SCIENCES AND TECHNOLOGIES

The position vector $\mathbf{r}_{\mathrm{i}-1, \mathrm{M}}$ of point $\mathrm{M}$ with respect to the system $i-1$ can be expressed by the relation:

$$
\mathbf{r}_{i-1, \mathrm{M}}=\mathbf{T}_{i-1, i} \mathbf{r}_{i \mathrm{M}}
$$

where:

$\mathbf{r}_{i \mathrm{M}}$ is the position vector of point $\mathrm{M}$ with respect to the system $i$,

$\mathbf{r}_{i-1, i}$ is the vector of the distance between the origin of the system $i$ with respect to the system $i-1$, $\mathbf{T}_{i-1, i}$ is the rotation matrix between the system $i$ and $i-1$.

The homogeneous transformation matrix is expressed by the relation:

$$
\mathbf{T}_{i-1, i}=\mathbf{T}_{\mathrm{z} 6}\left(\Theta_{i}\right) \mathbf{T}_{\mathrm{z3}}\left(\mathrm{d}_{i}\right) \mathbf{T}_{\mathrm{z} 4}\left(\alpha_{i}\right) \mathbf{T}_{\mathrm{z} 1}\left(a_{i}\right)
$$

We then write the position vector for Fig. 3a):

$$
\begin{gathered}
\mathbf{r}_{0 \mathrm{M}}=\mathbf{T}_{01}\left(\mathrm{q}_{1}\right) \mathbf{T}_{12}\left(\mathrm{q}_{2}\right) \mathbf{T}_{23}\left(\mathrm{q}_{3}\right) \mathbf{T}_{34}\left(\mathrm{q}_{4}\right) \mathbf{r}_{4 \mathrm{M}} \\
\mathbf{r}_{0 \mathrm{M}}=\mathbf{T}_{04} \mathbf{r}_{4 \mathrm{M}}
\end{gathered}
$$

where:

$$
\mathbf{T}_{04}=\mathbf{T}_{01} \mathbf{T}_{12} \mathbf{T}_{23} \mathbf{T}_{34}
$$

In our case, the individual transformation matrices will be in the form:

$$
\begin{aligned}
& \mathbf{T}_{01}=\mathbf{T}_{\mathrm{z6}}\left(\mathrm{q}_{1}\right) \mathbf{T} \mathrm{z} 3\left(\mathrm{~L}_{1}\right) \mathbf{T}_{\mathrm{z} 4}(\pi / 2) \\
& \mathbf{T}_{12}=\mathbf{T}_{\mathrm{z6}}\left(\mathrm{q}_{2}\right) \mathbf{T}_{\mathrm{z} 1}\left(\mathrm{~L}_{2}\right) \\
& \mathbf{T}_{23}=\mathbf{T}_{\mathrm{z6}}\left(\mathrm{q}_{3}\right) \mathbf{T}_{\mathrm{z} 1}\left(\mathrm{~L}_{3}\right) \\
& \mathbf{T}_{34}=\mathbf{T}_{\mathrm{z6}}\left(\mathrm{q}_{4}\right) \mathbf{T}_{\mathrm{z} 1}\left(\mathrm{~L}_{4}\right)
\end{aligned}
$$

Position of point $\mathrm{M}$ with respect to the coordinate system $\mathrm{O}_{4}, \mathrm{x}_{4}, \mathrm{y}_{4}, \mathrm{Z}_{4}$ is

$$
\mathbf{r}_{4 \mathrm{M}}=\left[\begin{array}{llll}
\mathrm{L}_{4} & 0 & 0 & 1
\end{array}\right]^{\mathrm{T}} \text {. }
$$

The following table (Table 1) shows the Denavit-Hartenberg parameters of the model of the robot (Fig. 3), [11-13]:

Table 1 -Denavit - Hartenberg parameters of the robot

\begin{tabular}{|c|c|c|c|c|}
\hline Body & $\Theta_{\mathrm{i}}$ & $\mathrm{d}_{\mathrm{i}}$ & $\alpha_{\mathrm{i}}$ & $\mathrm{d}_{\mathrm{i}}$ \\
\hline 1 & $\mathrm{q}_{1}$ & $\mathrm{~L}_{1}$ & 0 & $\pi / 2$ \\
\hline 2 & $\mathrm{q}_{2}$ & 0 & $\mathrm{~L}_{2}$ & 0 \\
\hline 3 & $\mathrm{q}_{3}$ & 0 & $\mathrm{~L}_{3}$ & 0 \\
\hline 4 & $\mathrm{q}_{4}$ & 0 & $\mathrm{~L}_{4}$ & 0 \\
\hline
\end{tabular}

The homogeneous transformation matrix between body members 4 and ground 0 is expressed by the relation in Matlab:

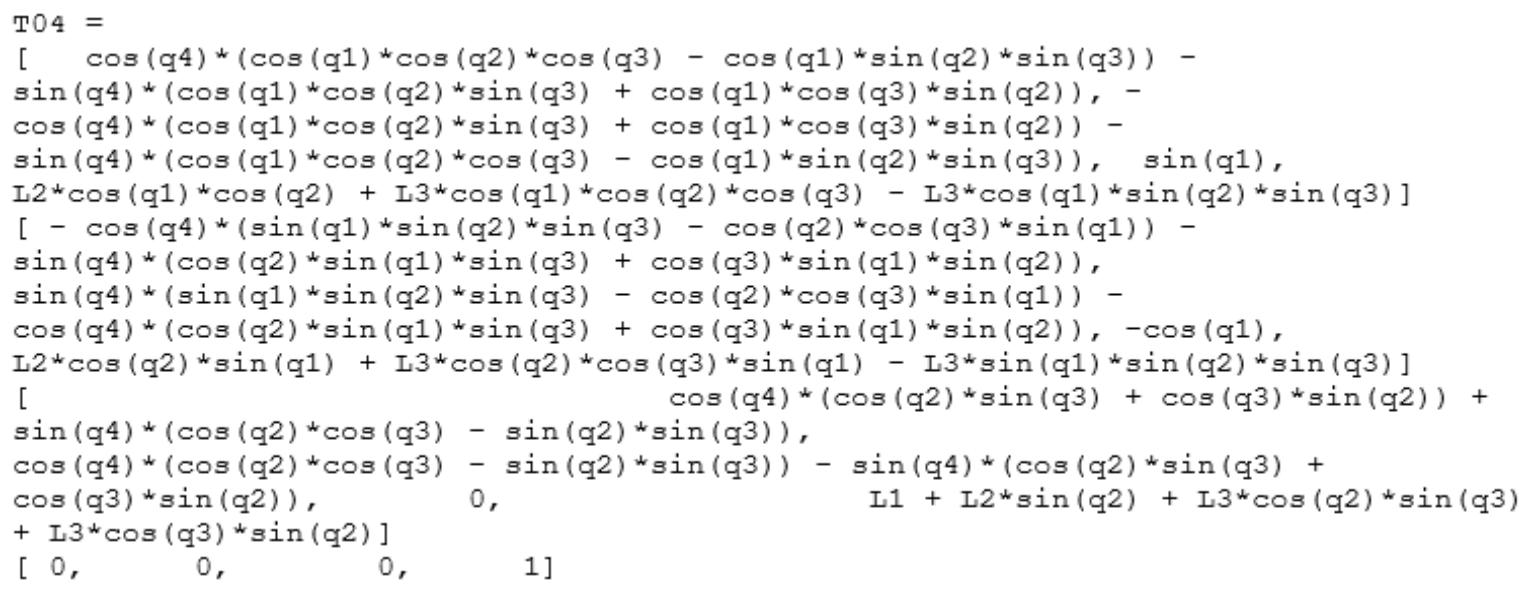

Component of the position vector $\mathbf{r}_{0 \mathrm{M}}$ is shown after solution in Matlab: 

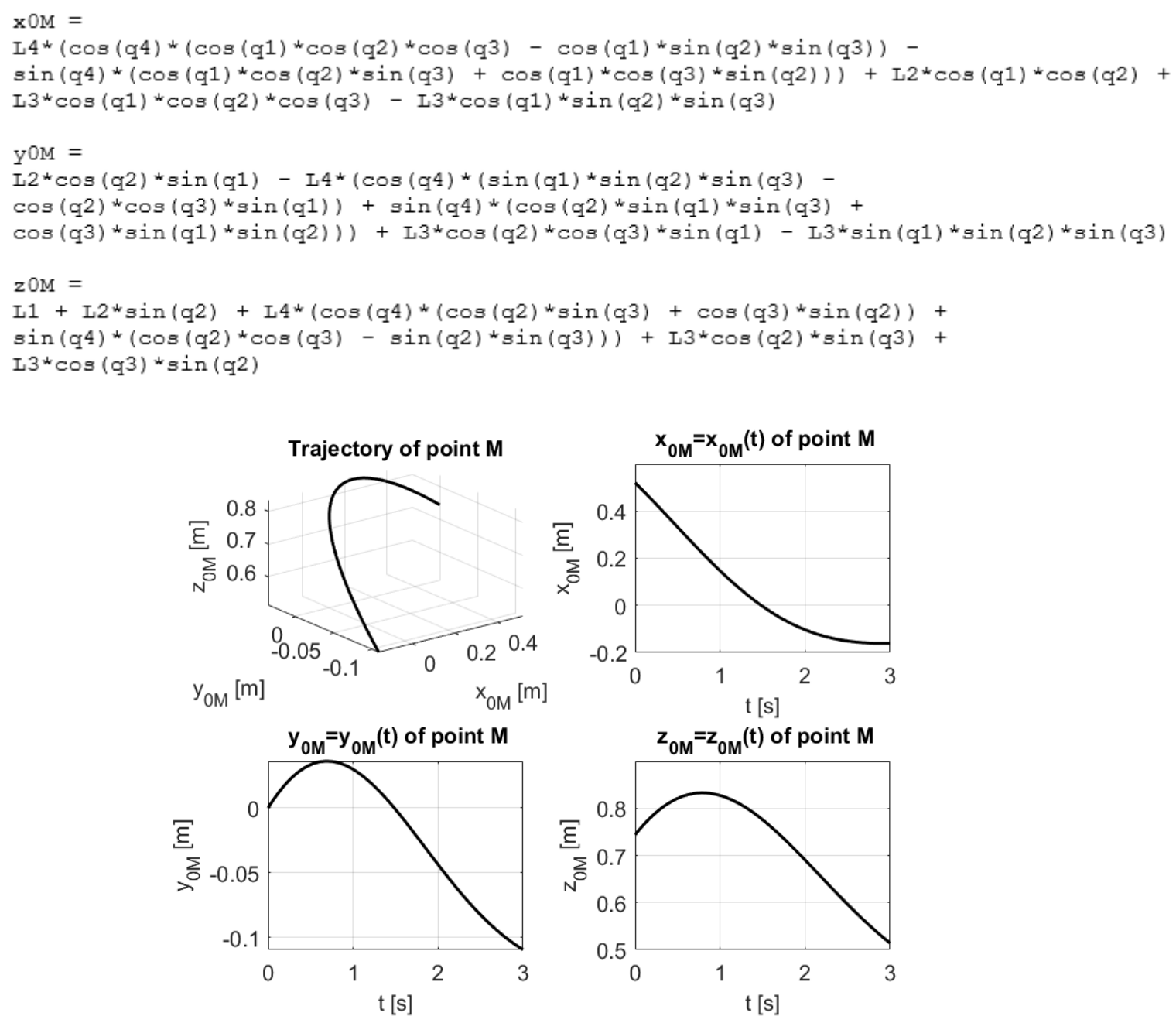

Fig. 5. Trajectory of the point of end-effector and $x, y, z$ position of the point of end-effector
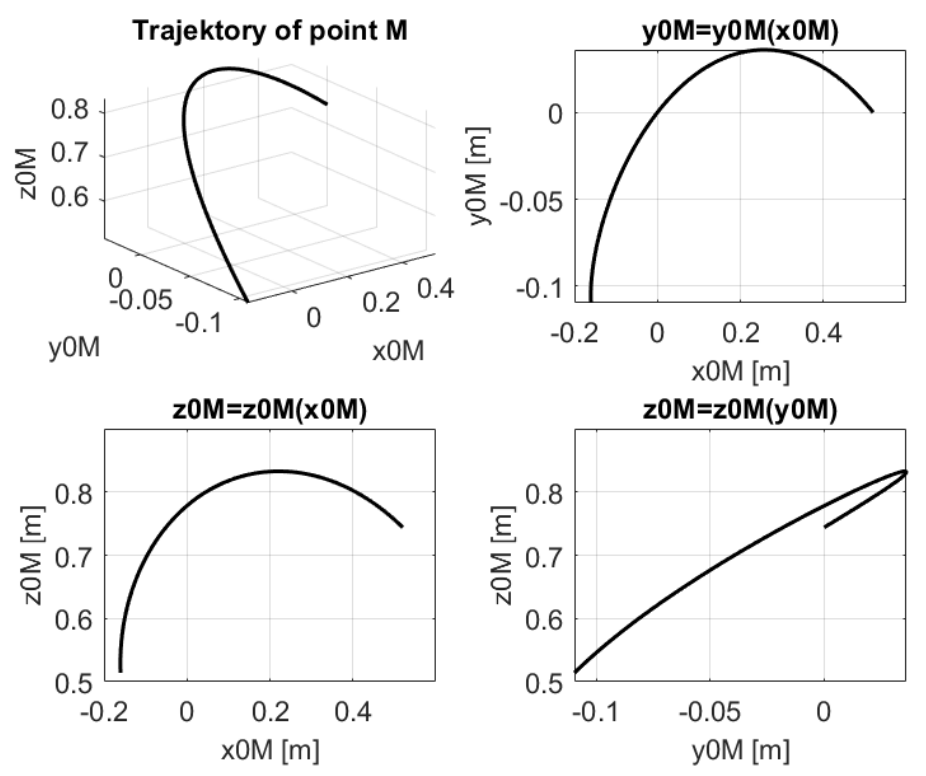

Fig. 6. Trajectory of the point of end-effector and $x, y, z$ position of the point of end-effector

Kinematic analysis of the model in MSC Adams software.

The next figure (Fig. 7) shows a manipulator model created in the MSC Adams/View. 
TECHNICAL SCIENCES AND TECHNOLOGIES

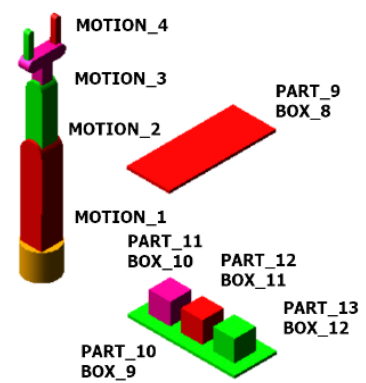

Fig. 7. Model of the robot in MSC Adams/View with platforms and boxes and motions in the joints

A 3D computer model of the manipulator is created in MSC Adams [8; 10]. Modelling elements and procedures for the creation of bodies and their kinematic bonds were used. After proposing the model, the functionality is verified and the simulation is started Fig. 8 [10-13].

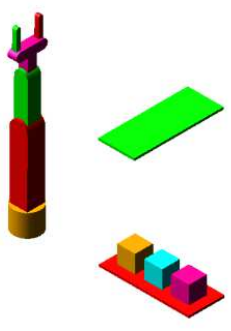

$a$

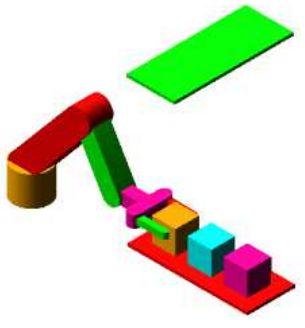

$b$

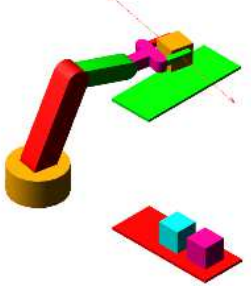

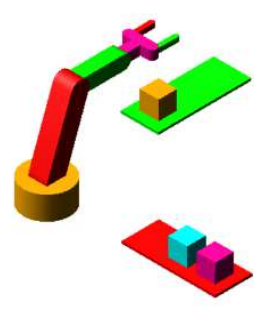

$d$

Fig. 8. Robot in the motion:

a-d-Robot with platforms and boxes and motions in the joints

The resulting graphs of trajectory of point of the end-effector obtained by the simulation are displayed in a graphical form with the postprocessor are in the following figures (Fig. 9, a-c).

The representation of the trajectory of the gripper's center of gravity in various views (Fig. 9, a-c) with defined movement in individual joints in Table 2 is shown below. The trajectory of the selected end member point is shown in Fig. 9 d) to f).

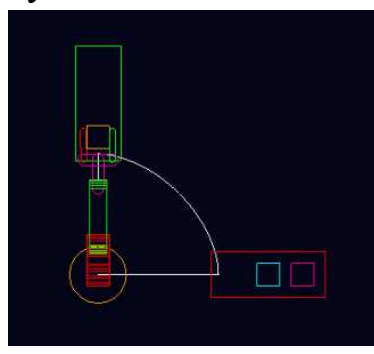

$a$

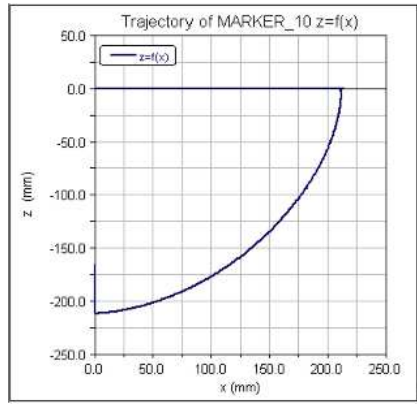

$d$

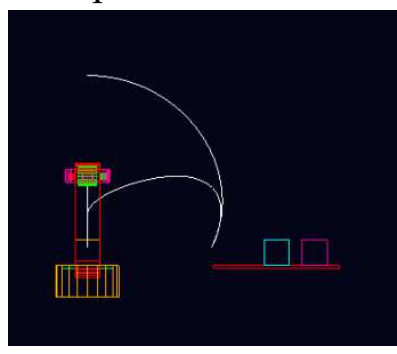

$b$

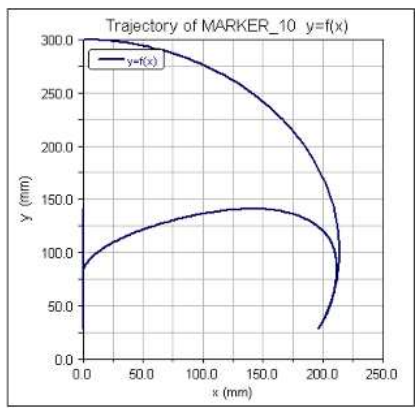

$e$

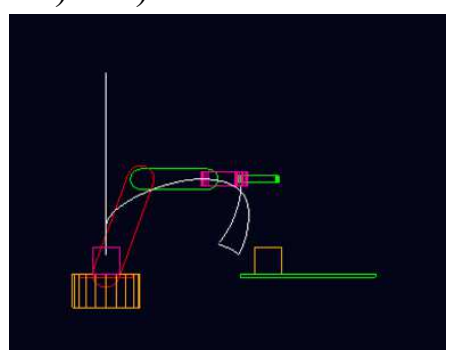

c

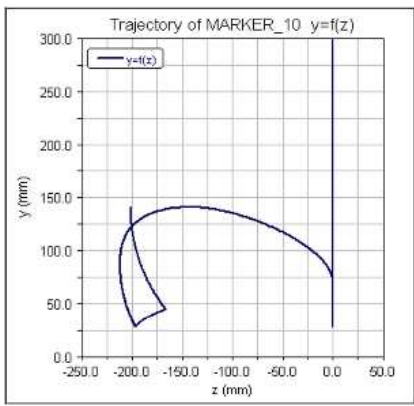

$f$

Fig. 9. Model with MOTION in Joint a)-c) and d) - f) trajectory of the point of end effector 


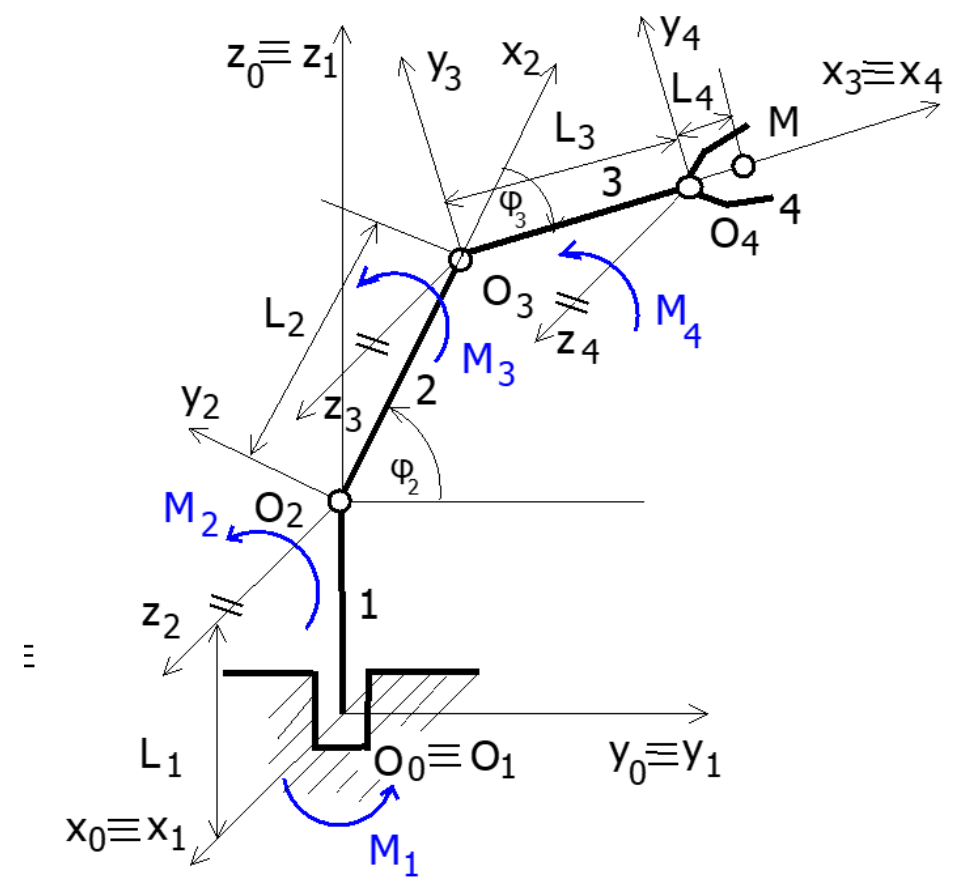

Fig. 10. Torque $M_{1}, M_{2}, M_{3}, M_{4}$ in the rotation joint

The movement MOTION_1, MOTION_2, MOTION_3 and MOTION_4 in the rotational joints of the robot is defined using the step function in Table 2.

Table 2 -Motion parameters of the robot

\begin{tabular}{|c|c|c|c|}
\hline ON 1 & ON 2 & ON 3 & $\mathrm{DN} 4$ \\
\hline STEP( time $, 1.5,0,2.5,-90 \mathrm{~d}$ ) & $\begin{array}{l}\text { STEP(time, } 0,0,1,-40 \mathrm{~d})+ \\
\text { STEP(time, } 1.1,0,2,20 \mathrm{~d})+ \\
\text { STEP(time, 2, 0, 3, -20d )+ } \\
\text { STEP(time, 3.1 , 0, 4, 20d ) }\end{array}$ & $\begin{array}{l}\text { STEP(time, } 0,0,1,-110 \mathrm{~d})+ \\
\text { STEP(time, } 1.1,0,2,40 \mathrm{~d})+ \\
\text { STEP(time, } 2,0,3,-40 \mathrm{~d})+ \\
\text { STEP(time, } 4.1,0,5,40 \mathrm{~d} \text { ) }\end{array}$ & $\begin{array}{l}\text { STEP(time, } 0,0,1,60 \mathrm{~d})+ \\
\operatorname{STEP}(\text { time } 1.1,0,2,-60 \mathrm{~d})+ \\
\operatorname{STEP}(\text { time }, 2,0,3,60 \mathrm{~d})+ \\
\operatorname{STEP}(\text { time }, 3.1,0,4,-60 \mathrm{~d})\end{array}$ \\
\hline
\end{tabular}

Conclusions. Interactive simulation and visualization allows comfortable simulation of the model, model modifications and visualization of results. The output graphs enable viewing the current values of the measured variables in real time during the actual simulation and its visualization.

Postprocessor is an integral part of the process of computer modeling of a prototype and it is a comfortable tool for creating, processing, modifying and presenting the results of simulation in the form of graphs $[8 ; 10]$. It is also possible to display the model in the current state and print the results prepared this way. It is also possible to create a video output of the simulation in AVI format.

We also calculated the position of the end effector point in the axis x, y, z (Fig. 8) [8-12]. The position of the point of the end-effector in the axis are shown.

MSC Adams works with a 3D model $[8 ; 10]$. The advantage is the possibility to simulate the motion of the prototype model and its control in the program environment and verification of the functionality in the form of 3D visualization. Based on the results obtained from the simulation it is possible to build a real model and design the drives. When designing drives for a mechanical system it is necessary to pay attention to the maximum magnitudes of the forces when handling various loads and so it is necessary to design the drive with the appropriate parameters for the specific purpose of use of the manipulator. 
TECHNICAL SCIENCES AND TECHNOLOGIES

Simulation software is a suitable tool for design, saving time and resources. It is also suitable for detailed research and investigation of mechanical systems in practice.

Acknowledgement. This work was supported in part by the Ministry of Education of the Slovakia Foundation under grant projects VEGA No. 1/0389/18, grant projects KEGA No. $018 T U K E-4 / 2018$ and grant projects No. 030 TUKE-4/2020.

\section{References}

1. Craig, J.J. (2005). Introduction to robotics: mechanics and control. Upper Saddle River: Pearson Prentice Hall.

2. Murray, R.M., Li, Z., \& Sastry, S.S. (1994). A Mathematical Introduction to Robotic Manipulation. University of California: CRC Press.

3. Paul, R.P. (1981). Robot manipulators, Mathematics, Programming and Control. Cambridge. MA: MIT Press.

4. Hartenberg, R.S., \& Denavit, J. (1955). A kinematic notation for lower pair mechenisms based on matrices. Journal of Applied Mechanics, 77, 215-221.

5. Brát, V. (1981). Maticové metódy v analýze prostorových vázaných systému. Praha: Academia.

6. Kozlov, V.V., Makaričev, V.P., Timofejev, A.V., \& Jurevič, E.I. (1984). Dynamika riadenia robotov. Nauka.

7. Stejskal, V, Valášek, M. (1996). Kinematics and dynamics of Machinery. Marcel Dekker.

8. Delyová, I., Frankovský, P., \& Hroncová, D. (2011). Kinematics analysis of movement of a point of a simple mechanism. In Modelling of mechanical and mechatronic systems 2011, The 4th International conference, TU Košice, Herl'any, Slovakia.

9. Gmiterko, A., Miková, L., Prada, E. (2018). Analysis of air-spring for a link of hyper-redundant manipulator. Technical sciences and technologies, 4(14), 66-77.

10. Vavro, J., Jr., Vavro, J., Kováčiková, P., Bezdedová, R., Híreš, J. (2017). Kinematic and dynamic analysis and distribution of stress in items of planar mechanisms by means of the MSC ADAMS software. Manufacturing Technology, 17(2), 267-270.

11. Miková, L. (2018). Didactic model of lift. Technical sciences and technologies, 3(13), 219-224.

12. Semjon, J., Kostka, J., Mako, P. (2018). Using the simulation program for the design and optimization of the production line. Technical sciences and technologies, 3(13), 61-67.

УДК 531.1:004

\section{Гронияова Дарина}

\section{КОМП'ЮТЕРНЕ МОДЕЛЮВАННЯ У MSC ADAMS / VIEW ЯК ЧАСТИНА СУЧАСНОГО ПІДХОДУ ДО ПРОСКТУВАННЯ МЕХАНІЧНИХ СИСТЕМ РОБОТІВ}

Розвиток комп'ютерних технологій виводить на передній план використання комп'ютерного моделювання механічних об'єктів. Вихідні дані величин, отримані в графічній формі під час моделювання, дозволяють оцінити поведінку моделі в реальному часі протягом робочого чиклу.

Існує кілька методів побудови кінематичної моделі робота. Найбільш поширеним методом є згода про кінематичне моделювання Денавіта-Хартенберга. Г. С. Каліџін також вирішував завдання для плоских $і$ сферичних механізмів за допомогою матричного обчислення. На можливість використання кватерніонів або бікватерніонов в кінематиці тіла вказав Й. Новак. Загальні методи аналітичного рішення обговорювалися С. Г. Кисліииним та Я. Ф. Морошкіним У кінематику просторових механізмів використання матричного обчислення ввів також чеський механік В. Брат.

Про дочільність і узагальненість використання матричного методу говорить не тільки можливість включення зазорів окремих членів безпосередньо в рівняння, але і зручність використання комп'ютера зі складними методами чисельного рішення систем рівнянь. Окремі рухи, які здійснюються одночасно, можна описати матричними рівняннями. Рішення матричним методом показано на зібраній моделі робота в програмі MSC Adams.

Метою роботи є вирішення прямої задачі кінематики в Matlab з використанням матричного методу $i$ моделювання робота за допомогою MSC Adams View. Результати рішення обробляються графічно в обох програмах. Основна мета полягала в тому, щоб отримати траєкторії кінцевих точок ефекторів робота як в Мatlab, так $i$ в MSC Adams / View. 
3D комп'ютерна модель маніпулятора створена в MSC Adams. Використано елементи моделювання і процедури формування тіл та їх кінематичних зв'язків. Після проєктування моделі перевіряється працездатність $i$ запускається прочес моделювання.

MSC Adams праџює з 3D-моделлю. Перевагою є можливість моделювання руху моделі-прототипу і управління нею в програмному середовищі, а також перевірка прачездатності у вигляді 3D-візуалізації. За результатами моделювання можна побудувати реальну модель і спроектувати приводи. При проєктуванні приводів для механічної системи необхідно звертати увагу на максимальну величину сил при роботі з різними вантажсами, і тому необхідно розробити привод із відповідними параметрами для конкретної иілі використання маніпулятора.

Ключові слова: маніпулятор; моделювання; кінематичний і динамічний аналіз; кінцевий ефектор; траєкторія. Рис.: 10. Табл.: 2. Бібл.: 13.

Hroncova Darina - PhD in Technical science, Department of Mechatronics, Faculty of Mechanical Engineering, Technical University of Kosice, (Letna 9, 04200, Kosice, Slovakia).

E-mail: darina.hroncova@tuke.sk

ORCID: http://orcid.org/0000-0002-5988-8353

SCOPUS Author ID: 55988359500

Hroncova, D. (2021). Computer modeling in MSC Adams/View as part of a modern approach to the design of mechanical systems of robots. Technical sciences and technologies, (2(24)), 23-32. 